\title{
Potential Impacts of Temperature Projections on Selected Large Herbivores in Savanna Ecosystem of Kenya
}

\author{
Mildred M. Aduma ${ }^{*}$, Gilbert Ouma ${ }^{1}$, Mohammed Y. Said ${ }^{2}$, Gordon 0. Wayumba ${ }^{3}$, \\ Philip A. Omondi ${ }^{1}$, Lucy W. Njino ${ }^{4}$ \\ ${ }^{1}$ Institute of Climate Change and Adaptation, University of Nairobi, Nairobi, Kenya \\ ${ }^{2}$ Center for Sustainable Drylands Ecosystems and Societies, University of Nairobi, Nairobi, Kenya \\ ${ }^{3}$ School of Surveying and Geospatial Sciences, Technical University of Kenya, Nairobi, Kenya \\ ${ }^{4}$ Directorate of Resource Surveys and Remote Sensing, Nairobi, Kenya \\ Email:^millyaduma@gmail.com,gilbertouma@gmail.com,msaid362@gmail.com,gowayumba@gmail.com, \\ philip.omondi@gmail.com,lnjino@gmail.com
}

How to cite this paper: Aduma, M.M., Ouma, G., Said, M.Y., Wayumba, G.O., Omondi, P.A. and Njino, L.W. (2018) Potential Impacts of Temperature Projections on Selected Large Herbivores in Savanna Ecosystem of Kenya. American Journal of Climate Change, 7, 5-26.

https://doi.org/10.4236/ajcc.2018.71003

Received: November 17, 2017

Accepted: February 9, 2018

Published: February 12, 2018

Copyright (c) 2018 by authors and Scientific Research Publishing Inc. This work is licensed under the Creative Commons Attribution International License (CC BY 4.0).

http://creativecommons.org/licenses/by/4.0/

\section{(c) (i) Open Access}

\begin{abstract}
Due to global land surface warming, severe temperature events are expected to occur more frequently and more extremely causing changes in biodiversity and altering movement and survival of large herbivores. There are increasing observations of escalating wildlife range losses worldwide. In this study, we investigated 15 large wild herbivores (4 migratory, 1 dispersing and 10 residents) and their potential range changes in relation to projected temperatures changes based on three Representative Concentration Pathways (RCPs) 2.6, 4.5 and 8.5. Previous studies of Kenyan savannah have shown that increases in temperature can reduce the densities of wildlife significantly and after certain thresholds the species can be lost in those landscapes. The range maps of the 15 species were developed from aerial censuses that have been conducted in the arid and semi-arid lands of Kenya. We analysed temperature changes for the three RCPs for the periods 2030s, 2050s and 2070s. And based on the temperature threshold for each of the 15 species we analysed which wildlife range areas will be lost. Our results project that for the RCP 2.6, 3 out of the 15 species are projected to lose more than $50 \%$ of their range by the year 2030s, and 5 out 15 by 2050s and 4 of 15 by 2070s. The second climate scenario of RCP 4.5 projects that by 2030s, 3 species will lose more than $50 \%$ of their range, and in 2050s and 2070s 5 species. The RCP 8.5 which is the extreme scenario of temperature changes projects 5 species to lose their range by $50 \%$ in 2030s, 7 species by 2050s and 10 species by 2070s. The extent of range loss was different among species but was severe for buffalo, Thomson's ga-
\end{abstract}


zelle, waterbuck, and wildebeest which are also water dependent species. However, the elephant, gerenuk, hartebeest, lesser kudu, and oryx are expected to retain most of their range in all the RCPs scenarios. These range contractions raise serious concerns about the future of wildlife in Kenyan savannah based on projected climate changes. And therefore, it is imperative the wildlife sector develops climate policies and plans that take into account the projected climate scenarios.

\section{Keywords}

Representative Concentration Pathways 2.6, 4.5 and 8.5, Species Range, Climate Adaptation and Management

\section{Introduction}

Since global warming debates in the 1970s, research has shown that every decade has been warmer than the previous ones and growing evidence insinuate that the past few decades are warmer than any others in past 2000 years [1]. On average, global temperature has increased by $0.72^{\circ} \mathrm{C}$ since 1950 [2]. The Intergovernmental Panel on Climate Change (IPCC) Fifth Assessment Report (AR5) predicts a continuous increase in global temperature if greenhouse gas (GHG) emissions continue unchanged. It further expects an increase in temperature between $0.3^{\circ} \mathrm{C}$ and $4.8^{\circ} \mathrm{C}$ by the end of $21^{\text {st }}$ century based on the emission scenarios [2] [3]. Increase of mean annual temperature has been reported at different spatial scales varying from local to national, regional, continental, hemispheric and global [4].

There has been an increase in globally averaged combined temperature both for the land and ocean surface of about $0.85\left[0.65^{\circ} \mathrm{C}\right.$ to $\left.1.06^{\circ} \mathrm{C}\right]$ from 1880 to 2012 [5]. Climate change may soon surpass the conventional human influence as the biggest driver of change in biodiversity over the coming century [6]. It is expected that there would be dynamic changes as some species enlarge their ranges to take advantage of newfangled suitable habitat, others move into new regions and form novel species relations, and many others alter their physiology, behavior, or preferred range in an attempt to adjust to the varying conditions. In savannah ecosystems climate change will influence wildlife unequivocally through shifts in temperature and water availability, and indirectly through effects on food sources, associated species, and habitat conditions [7]. Some animals will undoubtedly benefit from the future changes, while others may decrease or even go extinct-depending on the unique responses of species and populations [8].

Africa has been seen as one of the segments of the world extremely susceptible to the impacts of climate change [9]. It is projected that temperatures in the region are likely to increase more rapidly than the other parts of the world, which might surpass $2^{\circ} \mathrm{C}$ by midway of the $21^{\text {st }}$ century and $4^{\circ} \mathrm{C}$ by the close of the $21^{\text {st }}$ century [9]. IPCC AR5 has indicated that future rainfall predictions are more 
indeterminate but expected to intensify in the eastern Africa and decrease in the southern part [9]. Warmer temperatures are expected to occur in the East African region with a $5 \%-20 \%$ increase in rainfall from December-February and a $5 \%-10 \%$ decrease in rainfall from June to August by 2050 [10]. The stated variations are likely not to be uniform throughout the year and are expected to occur erratically. It is anticipated that the East African region will experience a reduction in the amount of precipitation received during the already dry season, which is likely to trigger more recurrent and severe droughts and increased desertification in the region. Previous investigation has indicated that the amounts of rainfall in Kenya have been lessening as from 1960 [11] and forecasts into the year 2029 indicate that some portions of the country will suffer more than 100 $\mathrm{mm}$ of rainfall decline [11].

As the climate continues to change, temperatures could become gradually significant, principally because it may be a key trigger of species extinction [12] [13]. The geographical distribution of plants and animals is expected to be influenced heavily by climate change [14] [15]. A study was done by [16]. [12] indicate that climate warming would cause species extinction of about $15 \%-37 \%$ by 2050. Recent studies by [13] reveal that out of the 177 mammals for which they had comprehensive data, all have lost at least $30 \%$ or more of their geographical ranges and more than $40 \%$ of the species have experienced severe population declines-more $80 \%$ range shrinkage. It is anticipated that birds may be very sensitive to climate change [17]. Estimates from two studies point to losses by 2100 due to climate change [13]. About $0.3 \%$ of the world's 8750 species of land birds are bound to be extinct [17] while up to $30 \%$ of the 8400 land bird species located in the Western Hemisphere could also go extinct [18]. Many species are already being driven to alter their geographic distributions and behavior as they respond to extreme weather patterns that are associated with human induced climate change [15].

Apart from climate affecting large herbivore other factors such as changes in land tenure systems, poor land use policies, human population pressure and the resulting settlements and fences, development of urban centers and formally semi-nomadic pastoralist in the savannah of East Africa becoming sedentary are adversely impacting wildlife [19]. However, the impacts of temperature have not been well understood. Recent studies by [20] indicate striking temperature rises in the arid and semi-arid lands (ASALs) of Kenya with annual average maximum temperature increases between $0.7^{\circ} \mathrm{C}$ to $1.9^{\circ} \mathrm{C}$ between 1960 and 2013 . The mean annual minimum temperature rose from $0.6^{\circ} \mathrm{C}$ to $1.7^{\circ} \mathrm{C}$ between the same periods displaying a more universal regional warming. Analysis on the relationship between wildlife densities and temperatures indicate that extreme minimum and maximum temperatures were linked to a reduction in the densities of all wildlife species except five: (gerenuk, lesser kudu, oryx, hartebeest and Grevy's zebra) which occurred at higher temperatures [20].

In this study we investigated the possible changes in wildlife ranges based on 
projected temperatures changes based on regional climate models. The simulations used for the projections are the Representative Concentration Pathways (RCPs), which are based on radiative forcings (globally radiative energy imbalance) measured in $\mathrm{Wm}^{-2}$ by the year 2100 [21]. The three RCPs used in this study are: the RCPs 2.6, 4.5 and 8.5, which represent the low, mid and high-level emission and concentration scenarios, respectively. The projected maximum temperatures were analysed for three future time slices 2030s, 2050s and 2070s to provide information on the expected magnitude of the climate response over each time window. The projected climates change signals for each time window are calculated as the difference between the future time windows and the reference period. In this study we analysed the impacts of projected climate change on 15 large wildlife species consisting of 4 migratory (wildebeest, zebra, Thomson's gazelle, eland) 1 dispersal (elephant) and 10 resident (buffalo, gerenuk, giraffe, Grant's gazelle, hartebeest, impala, Lesser Kudu, Oryx, warthog, and waterbuck) species in the county of Kajiado, a rich biodiversity wildlife area in East Africa. It hosts more than 50 mammal species, comprising the lion, cheetah, zebra, wildebeest and their predators. The study focused on the 15 species because they form the key large herbivores in the area and was based on the consistent availability of data from aerial census conducted between 1977 and 2016 [20] [22]. [20] also analyzed the relationship between the 15 species and temperature estimated their temperature thresholds.

\section{Materials and Methods}

\subsection{Study Area}

Kajiado County is primarily semi-arid as shown in Figure 1, and is located in

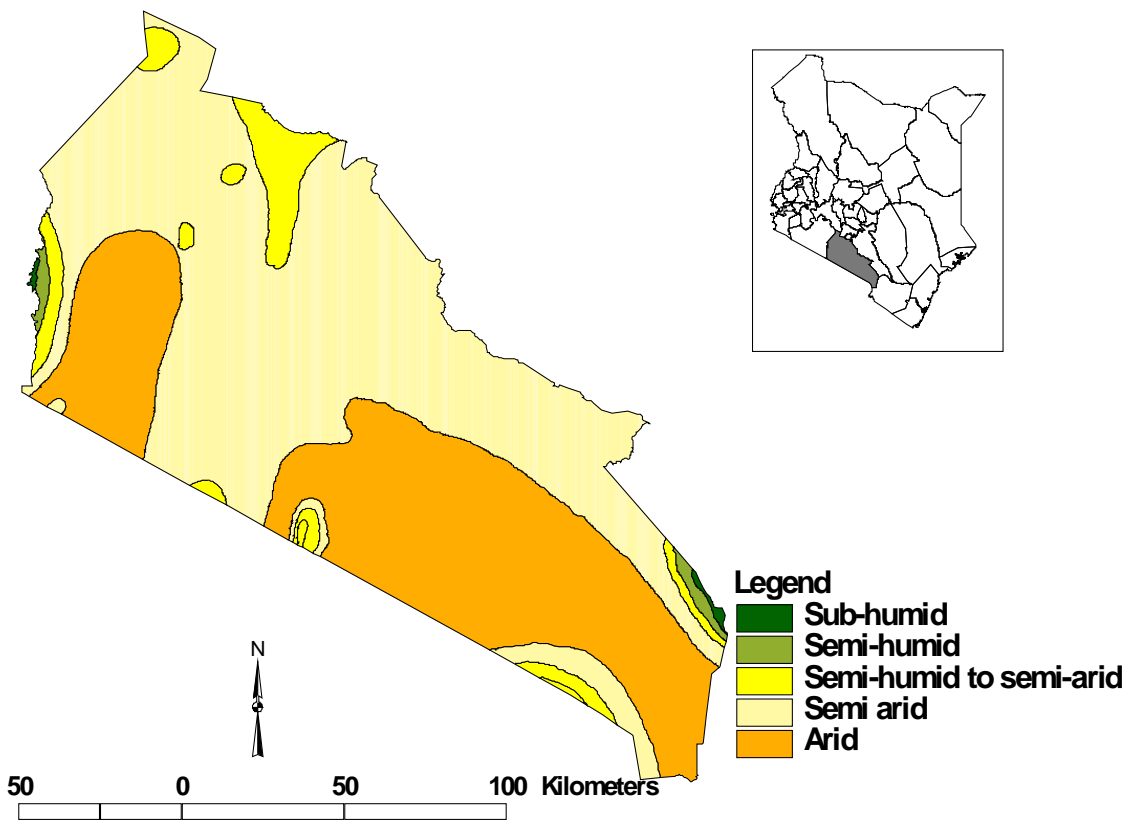

Figure 1. Study areamap showing Kajiado county in terms of agro-climatic zones. 
the southern tip of the former Rift valley province between longitudes $36^{\circ} 5^{\prime} \mathrm{E}$ and $37^{\circ} 55^{\prime} \mathrm{E}$ and $1^{\circ} 10^{\prime} \mathrm{S}$ and $3^{\circ} 10^{\prime} \mathrm{S}$. Its boundaries are: Tanzania to the south, Taita Taveta County to the west and Narok County to the east. It covers an area of $22,106 \mathrm{~km}^{2}$. It incorporates the Athi-Kaputiei ecosystem $\left(2200 \mathrm{~km}^{2}\right)$ in its northern part, the Greater Amboseli Ecosystem $\left(7730 \mathrm{~km}^{2}\right)$ to the east and the western Kajiado ecosystem $\left(11,389 \mathrm{~km}^{2}\right)$ to the west. Rainfall over the whole county is less than $600 \mathrm{~mm}$ except Ngong and Loitokitok areas. The county average maximum temperature is $26^{\circ} \mathrm{C}$ and average minimum temperature is $15^{\circ} \mathrm{C}$. The maximum temperature increases for Kajiado between 1960 and 2014 is reported to be $1.48^{\circ} \mathrm{C}$ while the minimum temperature increases are about $1.38^{\circ} \mathrm{C}[19]$.

Kajiado County is rich in wildlife species and also has some of the highest densities of wildlife [23] [24]. Wildlife not only exists in the National parks and gamereserves but throughout the county. There are, however, areas of wildlife conservation which include; the Kitengela Game Conservation area, Nairobi National Park, the Amboseli National Park, and the West Chyulu game conservation area. Apart from parks and conservation areas, wildlife concentration is high outside these protected areas. In general, wild animals migrate to higher areas or swamps during the dry spell, but in the wet season, they spread widely across the plains. The wildlife has co-existed with the livestock who are kept mainly by the Maasai pastoralist. The livestock helps in maintaining shorter grass which facilitate many of the wildlife population to thrive in these savannah ecosystem [20].

\subsection{Mapping Wildlife Distribution}

The wildlife range maps were generated by combining the wildlife surveys conducted in Kajiado between 1977 and 2014. In total 18 censuses were used to generate the range maps. The data were collected by the Directorate of Resource Surveys and Remote sensing (DRSRS) using a Systematic Reconnaissance Flight (SRF). High winged Partenavia aircraft equipped with GPS, intercom, and radar altimeters were used for aerial census. A crew of a pilot, two rear seat observers (RSO) and one front seat observer (FSO) were carried on every flight. The RSO were responsible for animal counts, while the FSO assists in navigation, crew coordination and records general environmental parameters. The county was surveyed along transects in east-west direction and spaced at $5 \mathrm{~km}$ intervals. Topographic sheets of scale 1:250,000 were used for flight planning and all transects conform to the Universal Transverse Mercator (UTM) projection system. Each transect was divided into equal sample sub units.

During surveys a standard flying height and flying speed was maintained. A calibrated survey strip width was defined by rods mounted on the aircraft and by window markings. Only animals observed within the survey strip were recorded during the survey. During the survey all visual observations by RSO of animals within the survey strip were recorded using tape recorders. For herds greater 
than 10 animals, a photo was also taken (refer to Appendix for photo for 2 key species). After every survey the tape recorded observations were transcribed to data sheets. Photos were processed and interpreted for animal species. Details of the methods and survey parameters are given in details in [20] [22].

In this research we studied 15 large wildlife species, 4 migratory, 1 dispersal and 10 resident species. The migratory species were wildebeest (Connochaetes taurinus), zebra (Equus burchelli), Thomson's gazelle (Gazella thomsoni) and eland (Taurotragus oryx). Elephant (Loxodonta africana) was assigned as dispersal species as it wanders seasonally but do not engage in regular seasonal migrations [25]. The 10 resident species included in this study were impala (Aepyceros melampus), warthog (Phacochoerus africanus), Grant's gazelle (Gazella granti), gerenuk (Litocranius walleri), Coke's hartebeest (Alcelaphus buselaphuscokeii), waterbuck (Kobus ellipsiprymnus), buffalo (Syncerus caffer), oryx (Oryx gazella), lesser kudu (Tragelaphus imberbis) and giraffe (Giraffa camelopardalis). Refer to Table 1 on details of the functional grouping of the residence and dietary guild of the species.

\subsection{Projected Climate Trends Based on Three RCPs $2.6,4.5$ and 8.5}

The IPCC report of 2013 [27] recommended a differentseries of scenarios known as Representative Concentration Pathways (RCPs) representing the full bandwidth of possible future emission trajectories. In this study, three Representative Concentration Pathways 2.6 (RCP 2.6), Representative Concentration Pathways 4.5 (RCP 4.5) and Representative Concentration Pathways 8.5 (RCP

Table 1. Functional groupings of species by residence guild and foraging guild.

\begin{tabular}{|c|c|c|c|c|}
\hline Common name & Scientific name & $\begin{array}{c}\text { Mass } \\
(\mathrm{kg})\end{array}$ & $\begin{array}{l}\text { Residence } \\
\text { guild }\end{array}$ & $\begin{array}{l}\text { Dietary } \\
\text { guild }\end{array}$ \\
\hline Wildebeest & Connochaetes taurinus & 120 & Migratory & Grazer \\
\hline Zebra & Equus burchelli & 200 & Migratory & Grazer \\
\hline Thomson's gazelle & Gazella thomsoni & 15 & Migratory & Grazer \\
\hline Eland & Taurotragus oryx & 350 & Migratory & Mixed feeder \\
\hline Elephant & Loxodonta Africana & 5500 & Dispersal & Mixed feeder \\
\hline Buffalo & Syncerus caffer & 700 & Resident & Grazer \\
\hline Gerenuk & Litocranius walleri & 49 & Resident & Browser \\
\hline Giraffe & Giraffa camelopardalis & 1250 & Resident & Browser \\
\hline Grant's gazelle & Gazel lagranti & 50 & Resident & Mixed feeder \\
\hline Hartebeest & Alcelaphus buselaphuscokeii & 125 & Resident & Grazer \\
\hline Impala & Aepyceros melampus & 40 & Resident & Mixed feeder \\
\hline Lesser Kudu & Tragelaphus imberbis & 90 & Resident & Browser \\
\hline Oryx & Oryx gazelle & 210 & Resident & Mixed feeder \\
\hline Warthog & Phacochoerus africanus & 45 & Resident & Grazer \\
\hline Waterbuck & Kobus ellipsiprymnus & 160 & Resident & Grazer \\
\hline
\end{tabular}

Modified from [25] and [26]. 
8.5) were used. The first scenario (RCP 2.6) represents an optimistic projection characterized by a very low concentration and emissions levels of greenhouse gases, medium rate of population growth, the radiative forcing peaks at $3 \mathrm{Wm}^{-2}$ in 2050 s before decreases in 2100 . The second scenario (RCP 4.5) is a scenario that stabilizes radiative forcing at $4.5 \mathrm{Wm}^{-2}$ in the year 2100 without ever exceeding that value. This scenario assumes that climate policies, in this instance the introduction of a set of global greenhouse gas emission prices, are invoked to achieve the goal of limiting emissions, concentrations and radiative forcing. The third scenario represents a pessimistic projection (RCP8.5) with high levels of concentrations and emissions of greenhouse gases, a high rate of population growth and radiative forcing reaches $8.5 \mathrm{Wm}^{-2}$ by the end of the century, this scenario does not implement climate change policies [28] [29].

The projected changes in temperatures for the three scenarios was based on three future time slices, 2030s (2016-2045), 2050s (2036-2065) and 2070s (2055$2085)$ to provide information on the expected magnitude of the climate response over each time window. The period 1971-2000 is considered as a reference for the present climate. The projected climates change signals for each time window are calculated as the difference between the future time windows (averages calculated over 30 years) and the reference period [30]. We calculated both the temporal and spatial changes.

The temporal temperature trends were modelled based on regression analysis for period 2006 to 2100 . To make a choice between the linear and quadratic models we used the corrected Akaike Information Criterion (AICc). The lower AIC was taken as the better model since they indicate a trade-off between the nonexistence of fit and the number of parameters in the model [31].

\subsection{Potential Impacts of Climate on Large Herbivore}

We adapted the framework developed by [20] to analyse the relationship of the large wild herbivore species with temperature. The two covariates (maximum and minimum temperatures) were related to the population size of each wild herbivore species using a generalized linear mixed model with a negative binomial error distribution and a log link function as shown in Figure 2. Each Species had their linear and quadratic models for each covariate chosen independently based on the corrected Akaike Information Criterion (AICc). The model fitting process automatically calculated the dispersion (scale) parameter of the negative binomial model and allowed for potential over dispersion and serial autocorrelation in population size. The models were fitted in the SAS GLIMMIX procedure.

\section{Results}

\subsection{Temporal and Spatial Projections of Temperatures}

\subsubsection{Maximum Temperature Projection for Kajiado}

Maximum temperature projection for Kajiado are shown in Figure 3. The analysis 
were based on the three RCPs. Temporal analysis of temperature changes for the three RCPs: 2.6, 4.5 and 8.5 in Kajiado indicate significant changes in maximum temperature for the period 2006 to 2100 . RCP 8.5 shows a steep increase in temperature (Figure 4 and Table 2). The temperature will increase from a base temperature $25.95^{\circ} \mathrm{C}$ in 2006 to about $30.35^{\circ} \mathrm{C}$ in 2100 . This will be an increase of about $4.4^{\circ} \mathrm{C}$. As for the RCP 4.5 the increases will be from a base temperature

a) Thomsons gazelle


h) Hunters hartebeest

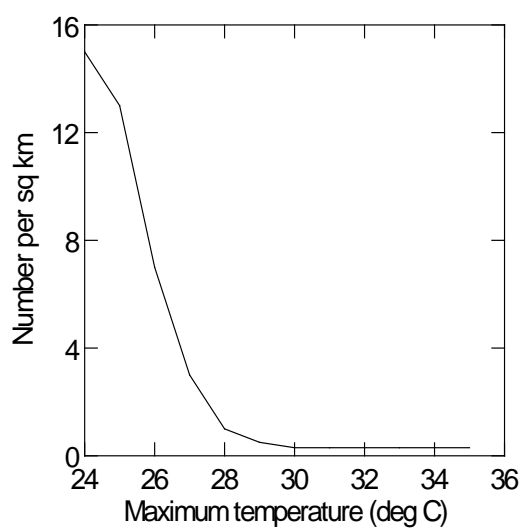

b) Impala
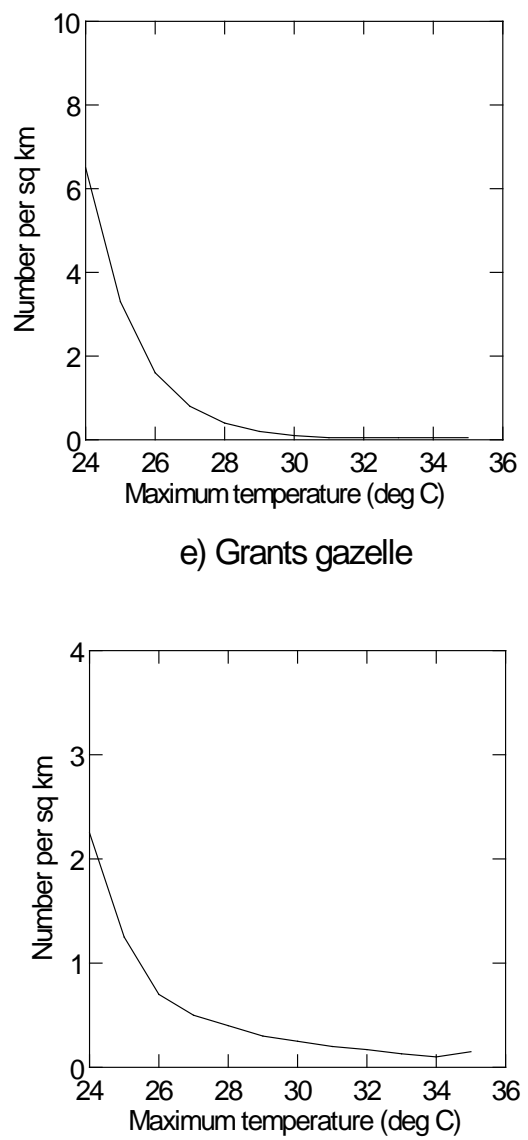

i) Wildebeest

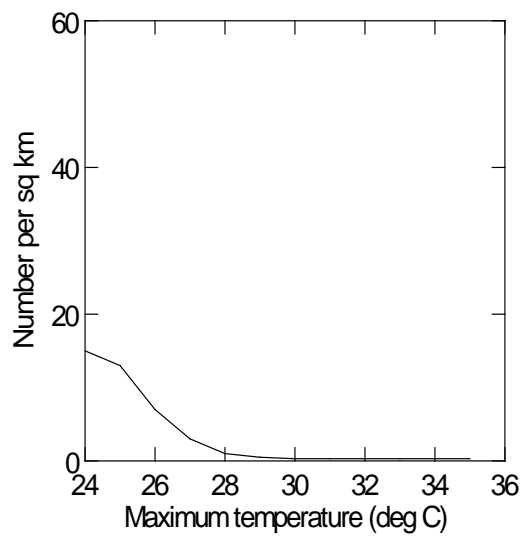

c) Warthog
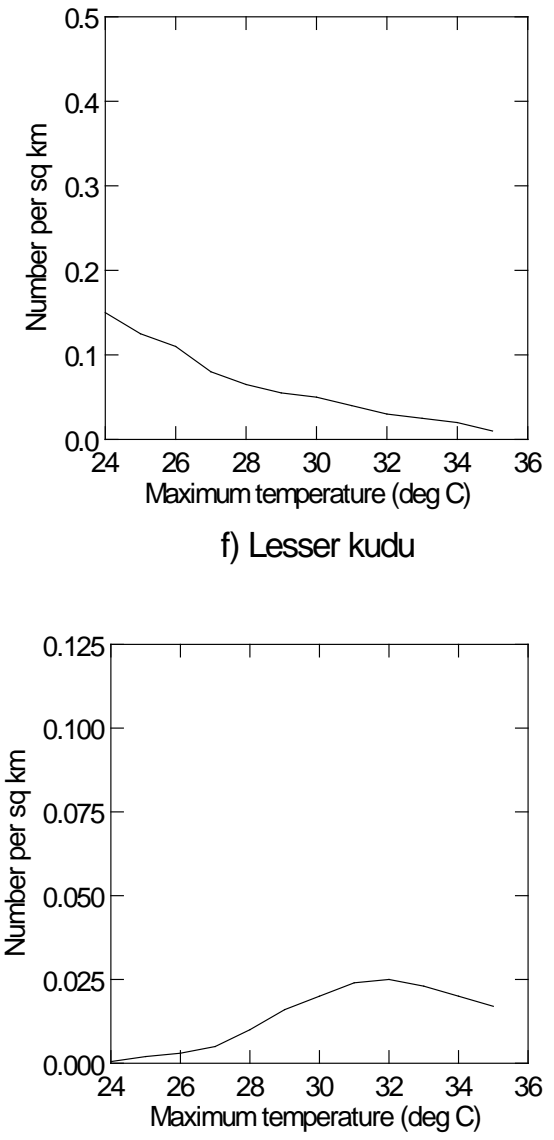

k) Waterbuck




h) Burchells zebra

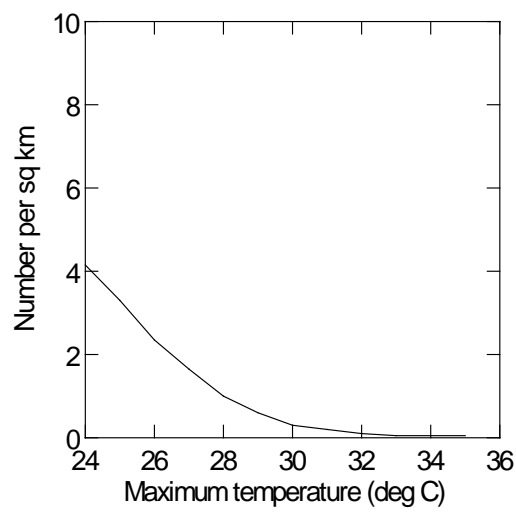

q) Buffalo

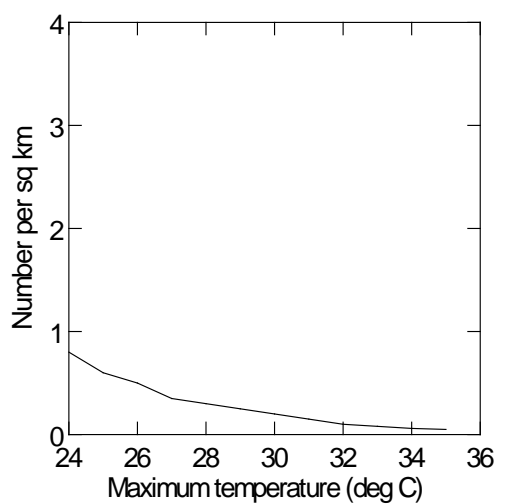

m) Oryx

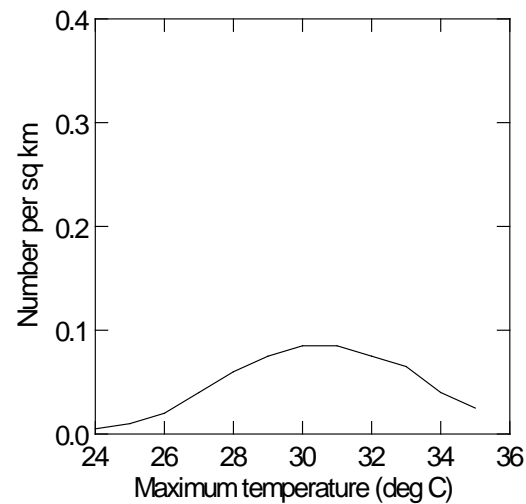

r) Giraffe

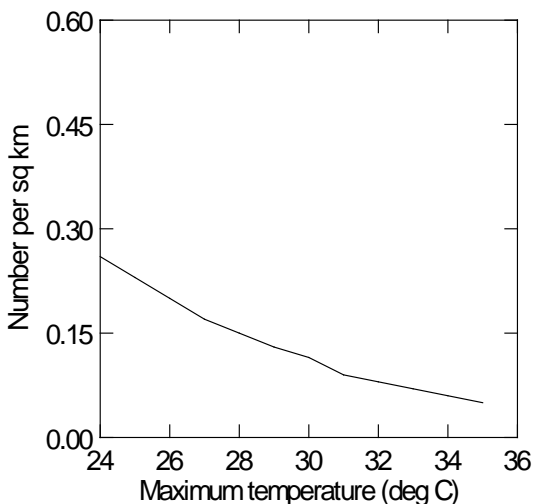

o) Eland

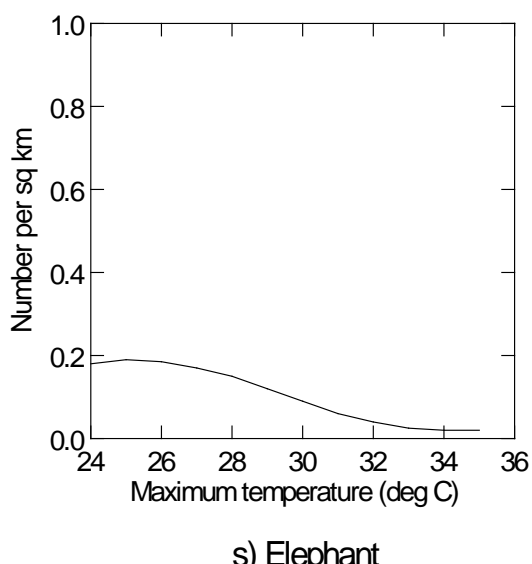

s) Elephant

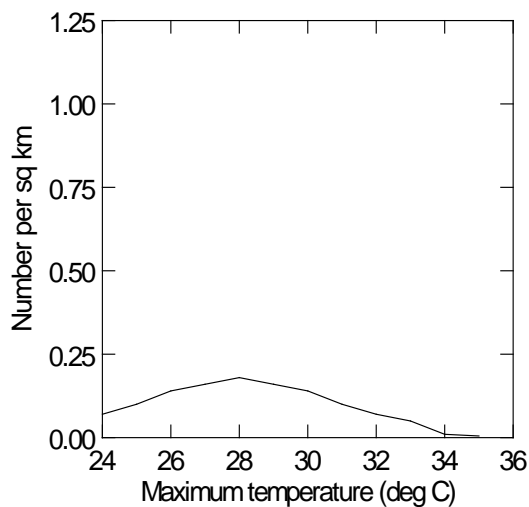

Figure 2. Relationships between the population density (number $/ \mathrm{km}^{2}$ ) of each of the 15 wildlife species and the annual average maximum temperature $\left({ }^{\circ} \mathrm{C}\right)$. Adapted and modified from $[20]$.

RCP 2.6 Maximum temperature



RCP 4.5 Maximum temperature



RCP 8.5 Maximum temperature

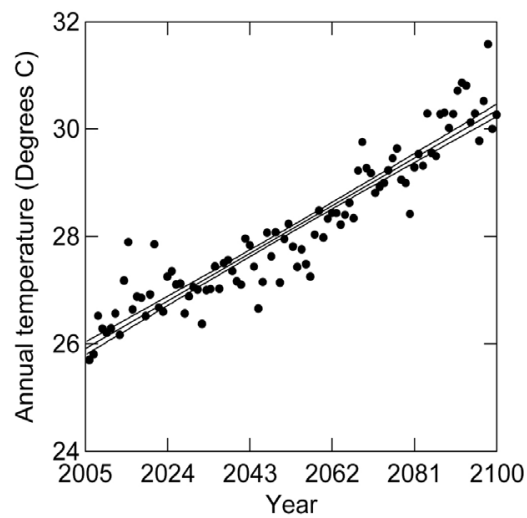

Figure 3. Maximum temperature projection for Kajiado for the three RCPs 2.6, 4.5 and 8.5 between 2006 and 2100.

of $26.4^{\circ} \mathrm{C}$ to about $28.1^{\circ} \mathrm{C}$ by 2100 . Finally RCP 2.6 projects maximum temperatures to increase from a base temperature of $26.18^{\circ} \mathrm{C}$ in 2006 to about $26.96^{\circ} \mathrm{C}$ in 2100. 
a) RCP2.6 2030's



d) RCP4.5 2030's

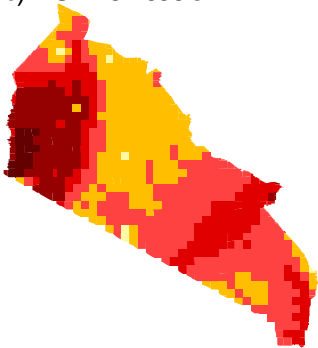

g) RCP8.5 2030's



18 - 22.4 b) RCP2.6 2050's

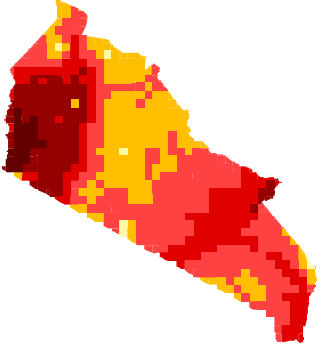

e) RCP4.5 2050's

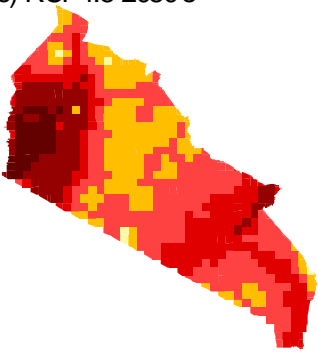

h) RCP8.5 2050's

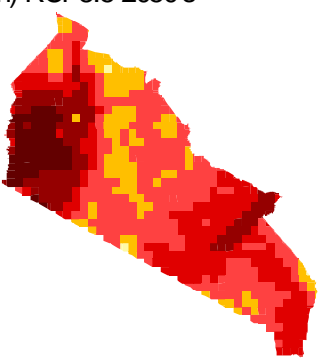

c) RCP2.6 2070's



f) RCP4.52070's



i) RCP8.5 2070's

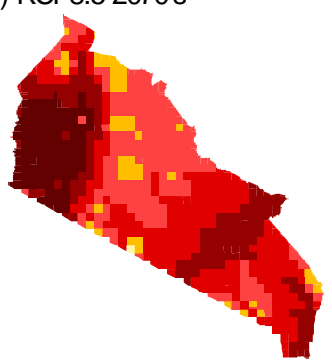

31.6 - 33.9

33.9 - 36.9

Figure 4. Spatial projections of maximum temperatures changes in Kajiado counties based on RCPs 2.6, 4.5 and 8.5 scenarios for the period 2030s, 2050s and 2070s.

Table 2. Projection of maximum temperature for the three RCPs.

\begin{tabular}{ccccc}
\hline RCP & Equation & $\mathbf{R}^{2}$ & F Ratio & P Value \\
\hline RCP2.6 & $\mathrm{Y}=-1501.9977+1.48693 \mathrm{x}-0.00036 \mathrm{x}^{2}$ & 0.280 & 17.822 & $<0.0001$ \\
$\mathrm{RCP} 4.5$ & $\mathrm{Y}=-10.0754+0.01817 \mathrm{x}$ & 0.563 & 119.812 & $<0.0001$ \\
$\mathrm{RCP} 8.5$ & $\mathrm{Y}=-67.70979+0.04669 \mathrm{x}$ & 0.876 & 655.686 & $<0.0001$ \\
\hline
\end{tabular}

The spatial analysis of the temperature projections indicates western sections and Amboseli ecosystem as the hotspot for temperature changes (Figure 4). In these areas the temperatures are projected to be between $29^{\circ} \mathrm{C}$ and $37^{\circ} \mathrm{C}$. The central plains and Athi Kaputei plains are projected to have moderate temperature increases for the RCP 2.6 (2030s, 2050s and 2070s-as shown in Figures 4(a)-(c)), and RCP 4.5 (2030s and 2050s-Figure 4(e) and Figure 4(f)) and RCP 8.5 (2030s-Figure 4(g)). However, for the RCP 4.5 (2070s), and RCP 8.5 (2050s and 2070s) these areas are projected to have significant increases in temperature. Table 3 shows that by 2070 the temperatures are projected to increase by $+1.10,+1.83$, and +3.09 for RCPS $2.6,4.5$, and 8.5 respectively. 
Table 3. Temperature projections $\left({ }^{\circ} \mathrm{C}\right)$ for the $3 \mathrm{RCPs}$ for the periods of $2030 \mathrm{~s}, 2050 \mathrm{~s}$, 2070s.

\begin{tabular}{cccc}
\hline RCP & $2030 \mathrm{~s}$ & $2050 \mathrm{~s}$ & $2070 \mathrm{~s}$ \\
\hline RCP 2.6 & +1.16 & +1.26 & +1.10 \\
RCP 4.5 & +1.00 & +1.55 & +1.83 \\
RCP 8.5 & +1.36 & +1.99 & +3.09 \\
\hline
\end{tabular}

\subsubsection{Species Range Distribution}

The distribution of the 15 wildlife species in Kajiado varied (Figure 5). The larger geographical ranges in the study area are occupied by the giraffe, impala, Thomson's gazelle, eland and the Grant's gazelle. They are spread out in the entire area and their pattern of distribution is almost similar. The wildebeest and the Burchell's zebra which are migratory species, have concentrated mainly to the north (the Athi Kapuitei), southern part (Amboseli ecosystem), and western section of the county and avoiding the central region.

The geographical distribution of the gerenuk, hartebeest, lesser kudu, oryx and warthog is much restricted to certain landscapes. Gerenuk and lesser kudu geographical distribution is restricted in the central and the Amboseli ecosystem. The warthog is sparsely spread in the northern parts of Kajiado but fairly distributed from the central region towards Amboseli ecosystem. The range of the oryx is restricted to the western Kajiado and in Amboseli ecosystem avoiding high altitude areas. The hartebeest deviated from this pattern by concentrating in high altitude areas like the Chyulu hills, Athi Kaputei, Ngong hills and sparingly in the southern plains of Kajiado.

The large size wildlife like the elephant, buffalo and waterbuck displayed a very narrow range altogether. They are mostly distributed in Amboseli ecosystem and western sections of the county around the Nguruman forests, areas close to water resources sources (wetlands and forest).

\subsubsection{Range Changes}

We analyzed the changes in temperature for the three RCPs for the periods 2030, 2050 and 2070. And based on the temperature threshold for each of the 15 species, we analysed which wildlife range areas will be lost. Based on the results of this study, RCP 2.6 projects that at least 3 out of the 15 species would lose more than $50 \%$ of their range by the year 2030; 5 out 15 by 2050 and 3 out 15 by 2070 (Figure 6(a)). In the second scenario of RCP 4.5 it is projected that by 20303 species will lose more than $50 \%$ of their range. The number would increase to 5 species in the year 2050 and 2070 (Figure 6(b)). In the third and final scenario of RCP 8.5 which is the extreme scenario of temperature changes, it is projected that 5 species are likely to lose more than $50 \%$ of their range by 2030, 7 species by 2050 and 10 species by 2070 (Figure 6(c)). The extent of range loss differed amongst species but was largely extreme for buffalo, Thomson's gazelle, waterbuck, and wildebeest the water dependent species. The four species are expected to lose between $48 \%$ - $96 \%$ of their range based on RCP $2.6 ; 46 \%$ - 97\% based on 
a) Buffalo

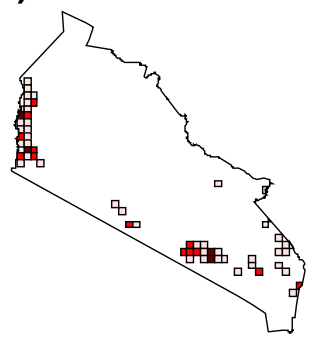

d) Gerenuk

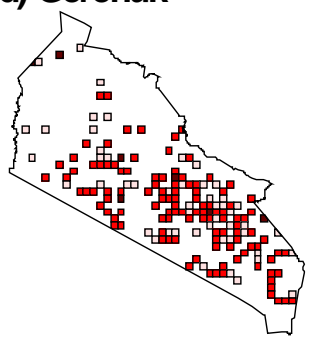

g) Hartebeest

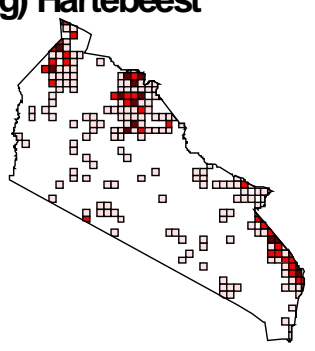

j) Oryx



m) Waterbuck

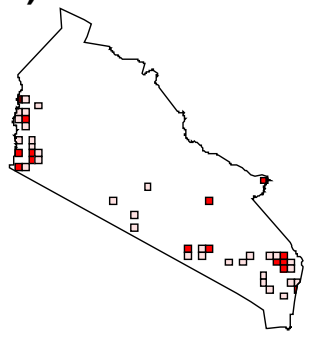

b) Elephant

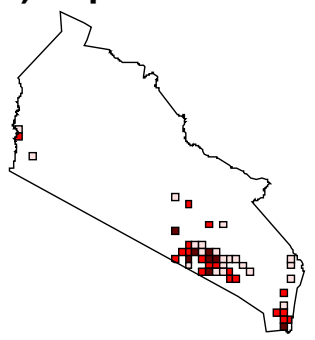

e) Giraffe

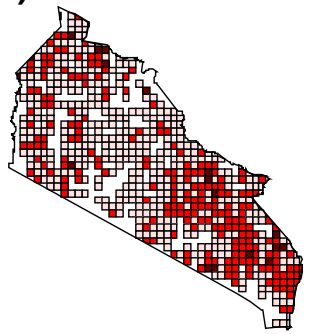

h) Impala



k) Thomson's gazelle

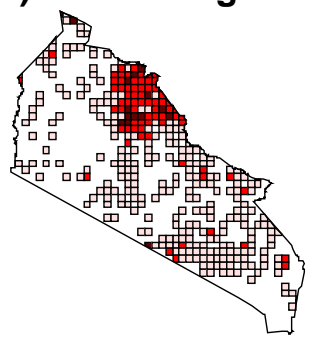

n) Wildebeest

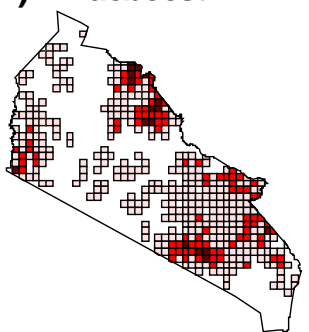

c) Eland

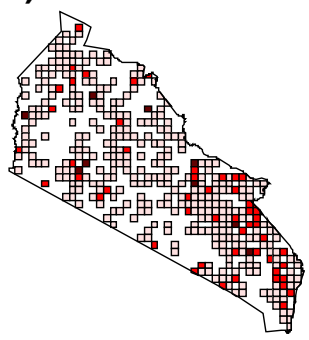

f) Grant's gazelle

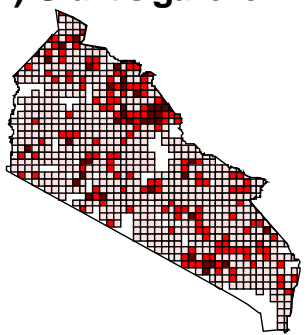

i) Lesser kudu

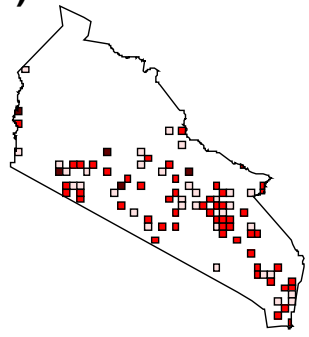

I) Warthog

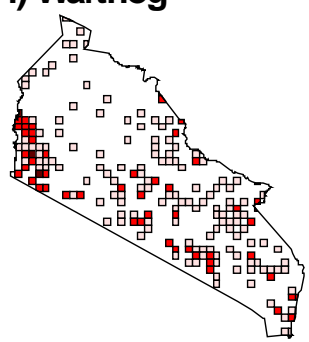

o) Zebra



Figure 5. Species range map for the 15 wildlife species in Kajiado county.

RCP 4.5 and 51\% - 98\% based on RCP 8.5. However, the elephant, gerenuk, hartebeest, lesser kudu, and oryx are expected to retain most of their range in all the RCPs scenarios. The range lose are minimal at $4 \%-27 \%$ (RCP 2.6); $4 \%-23 \%$ (RCP 4.5) and 2\% - 31\% (RCP 8.5). 
RCP2.62030

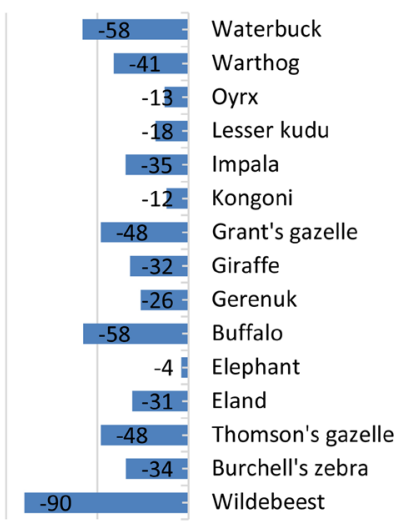

$\begin{array}{lll}-100 & -50 & 0\end{array}$



RCP8.5 2030

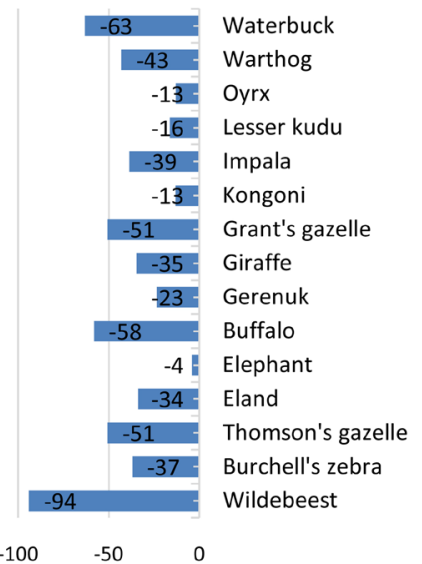

RCP2.6 2050

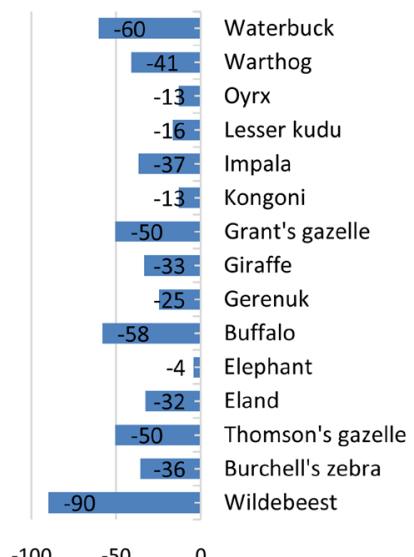

(a)



(b)

RCP8.5 2050



(c)
RCP2.6 2070

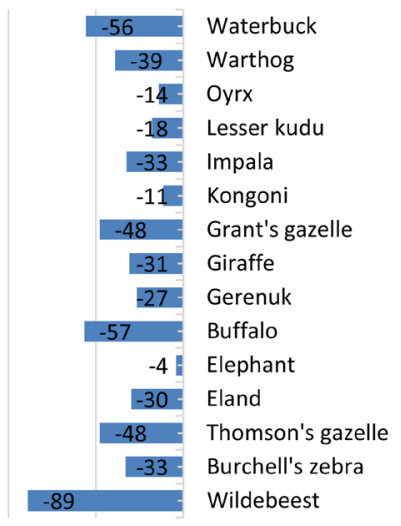

$\begin{array}{lll}-100 & -50 & 0\end{array}$ 


\section{Discussions}

In this study we used the Regional Climate Models (RCM) with a better data resolution. The RCM clearly simulate the interactions between the large-scale weather patterns simulated by a global model and the local terrain. The results indicate that maximum temperatures for Kajiado are projected to increase by $1.7^{\circ} \mathrm{C}$ between 2006 and 2100 based on RCP 4.5. As for the RCP 8.5 it is expected to increase by $4.4^{\circ} \mathrm{C}$ between 2006 and 2100 . These temperature increases are more than what has been projected for the region. Studies based on historical temperature analysis for Kajiado have indicated that there is regional warming in the region [20]. The trend towards increasing frequency and intensity of droughts and rising temperatures will affect species range in Kenyan savannas negatively. The three RCPs projected temperature increases would impact the herbivores differently since there will be both spatial and temporal differences. RCP 2.6 projects a temperature increase of $1.16^{\circ} \mathrm{C}$ by $2030 \mathrm{~s}, 1.26^{\circ} \mathrm{C}$ by $2050 \mathrm{~s}$, and $1.10^{\circ} \mathrm{C}$ by $2070 \mathrm{~s}$. RCP 4.5 projects temperatures to increase by $1.00^{\circ} \mathrm{C}$ in the $2030 \mathrm{~s}, 1.55^{\circ} \mathrm{C}$ in $2050 \mathrm{~s}$ and $1.83^{\circ} \mathrm{C}$ by 2070 s. The projections for RCP 8.5 show there will be extremely higher temperature increases with an increase of $1.36^{\circ} \mathrm{C}$ by the $2030 \mathrm{~s}, 1.99^{\circ} \mathrm{C}$ in the $2050 \mathrm{~s}$ and $3.09^{\circ} \mathrm{C}$ in the 2070 s. Generally the temperatures in Kajiado have increased from 2006 to 2070. RCP 8.5 shows higher maximum temperature increases of about $3.09^{\circ} \mathrm{C}$ which is above $2^{\circ} \mathrm{C}$ that is projected globally. RCP 4.5 on the other hand projects an increase of about $1.83^{\circ} \mathrm{C}$ by the year 2070 .

In terms of spatial projection of maximum temperature it is projected that there will be increases of between $29^{\circ} \mathrm{C}$ and $37^{\circ} \mathrm{C}$ in the south western sections of Amboseli ecosystem and moderate temperature increases of approximately $22^{\circ} \mathrm{C}$ to $27^{\circ} \mathrm{C}$ in the central plains and Athi Kaputei plains. Species that have most of their range concentrated in west Kajiado and small sections of the semi-arid central plains will begin to feel the impacts of the increasing temperatures as they try to adapt to the escalating maximum temperatures. The waterbuck, wildebeest, buffalo, Oryx, warthog and zebra are likely to lose most of their range in Kajiado West by 2030s. The RCP 8.5 will increase by $1.99^{\circ} \mathrm{C}, \mathrm{RCP} 4.5$ by $1.55^{\circ} \mathrm{C}$ and RCP 2.6 by $1.26^{\circ} \mathrm{C}$ by the 2050s. The range loss will continue in the hotspot areas (Western Kajiado and central plains) affecting mainly the species located in these areas. As the 2070s approach most of the species in the hot spot areas will experience very high temperatures that will impact them negatively since there will be an increase in unsuitable areas for the species [20]. RCP 2.6 Projects an increase of $1.10^{\circ} \mathrm{C}, \mathrm{RCP} 4.5$ projects $1.83^{\circ} \mathrm{C}$ and 8.5 projects $3.09^{\circ} \mathrm{C}$. With the high increases by 2070 s the central plains hotspot is also increasing in size and most of the species will undergo increased contraction of their range sizes.

The range size of the 15 species studied declined by an average of about $50 \%$ between 2006 and 2070 in western Kajiado, central plains and Amboseli ecosystems. For the RCP 2.6, it is projected that 3 out of the 15 species would lose more than $50 \%-70 \%$ of their range by 2030 s, 7 out 15 would lose more than $30 \%$ - 
$50 \%$ of their range by 2030 s and 5 of 15 would lose less than $30 \%$ of their range by 2030s. The second climate scenario of RCP 4.5 projects that by 2030s, 3 species will lose more than $50 \%-70 \%$ of its range, 7 out of 5 would lose more than $30 \%-50 \%$ of their range by 2030 s and finally 5 of 15 would lose less than $30 \%$ of their range by 2030s RCP 8.5 projects that 5 out of the 15 species would lose more than $50 \%-70 \%$ of their range by 2030 s. 5 out 15 would lose more than $30 \%-50 \%$ of their range by 2030 s and 5 of 15 would lose less than $30 \%$ of their range by 2030 s.

In the 2050s the RCPs project different range loses for the various species. RCP 2.6 projects 5 species to lose between $50 \%-70 \%$ of their range, another 5 to lose between $30 \%-50 \%$ of their range and final 5 to lose less than $30 \%$ of their range. On the contrary RCP 4.5 projects 7 out 15 species would lose more than $50 \%-70 \%$ of their range by 2050 s, while 3 other species would lose between $30 \%$ $50 \%$ of their range and an additional 5 would lose less than $30 \%$ of their range by 2050s. The same scenario is repeated for RCP 8.5 where 7 out 15 species would lose more than $50 \%-70 \%$ of their range by 2050 s and 3 species would lose between $30 \%-50 \%$ and 5 would lose less than $30 \%$ of their range by 2050 s.

Range loss projections for the 2070s are much higher than the previous years for RCP 4.5 and 8.5 but lower for RCP 2.6 which projects 3 out of the 15 species to lose more than $50 \%-70 \%, 8$ out 15 to lose between $30 \%-50 \%$ and 4 to lose less than $30 \%$ of their range. RCP 4.5 projects 5 out of the 15 species to lose more than $50 \%-70 \%$ of their range, another 5 to lose $30 \%-50 \%$ and the final 5 to lose less than $30 \%$ of their range. On the extreme is the RCP 8.5 which projects at-least 10 out of the 15 species to lose more than $50 \%-70 \%$ of their range, 2 species to lose between $30 \%-50 \%$ and 3 species to lose less than $30 \%$ of their range.

The magnitude of range loss varied among species but was most extreme for buffalo, Thomson's gazelle, waterbuck, wildebeest and the grants gazelle. Most of these animals have a small range; big bodies sizes, and are water dependent. Previous studies have indicated that body size of mammals are positively correlated with extinction risk [32] [33] [34]. Past studies have also indicated that the buffalo population declined tremendously during the 2008-2009 drought while that of the waterbuck and Thomson's gazelle had been declining continuously before the drought and it dropped distressingly to very low levels after the drought [23]. The impact of migratory species was high and the impacts on wildebeest as projected will be extremely severe.

The wildebeest is projected to be among the five most vulnerable species since its range will reduce by $98 \%$. This species is migratory and its temperature threshold is about $28^{\circ} \mathrm{C}$. Higher temperatures will pose an additional challenge to its movement process. Historically, wildebeests have been affected by housing developments, land fragmentation through fencing and poaching activities especially in central plains and Athi-Kaputei plains [19]. Growth and escalation of land use developments coincided with the dramatic population declines and 
range contractions of the wildebeest [35]. In the Athi-Kaputiei ecosystem, the wildebeest migration between the Nairobi National Park and the adjoining AthiKaputiei Plains dropped by more than 90\%, from over 30,000 in 1978 to below 2000 by 2011 due to ever-increasing urbanization, fencing, settlements, mining and other developments [19] [34]. With climate change as an additional threat it is expected that there will be an increase in the frequency and severity of extreme events and shocks, such as droughts and floods [36]. Land fragmentation coupled with Climate change will interact with one another, such that increasing fragmentation will limit the agility and movement of the wildebeests thereby threatening their survival. The population viability of this species is not guaranteed since other drivers are also leading to the decline of the population. [20]. Increase in temperatures will have a negative impact on the species because they are migratory in nature. In addition wildlife corridors are being blocked by land a use change which further complicates the adaptation strategy of the animals.

On the contrary the elephant, gerenuk, hartebeest, lesser kudu, and oryx are expected to retain most of their range in all the RCPs scenarios as the increase in temperature are within the species ranges. Other studies have shown that elephant population have also increased persistently in Kajiado east from 2000 to 2011 [23] [24] [37]. Therefore despite the increase in temperatures the elephant range is not threatened mainly because they are found in the Amboseli region which is relatively low temperature and has many swamps that guarantee their survival. Other studies have demonstrated that elephant can survive extreme climate as indicated in the studies in Namibia [38] and increasing elephants in Botswana [39], where the condition are much severe than our study area. In Kajiado the other drivers like settlements, agriculture, land subdivision and developments may impact the elephants negatively. Most of the elephant corridors have been partially blocked [40] which might impact the elephant distribution.

The results of this study underscore the use of a blended regional-and species-level assessment and reiterate the need to address both physiological and physiographic factors in order to broadly comprehendglobal warming impacts on large herbivores of East African savanna. We speculate that among the large herbivores, a reduction in range sizes in the twenty-first century may be worse than in the best case scenario. With the intensifying temperatures it may be necessary for the animals to flee from the heat, forcing them to move to unsafe habitats. Ininsecurehabitats, the animal's survival rate might decrease to a point where the population is no longer viable. If a suitable habitat is not available due to factors like human disturbance, the animals might face extinction.

High temperatures have great impacts on wildlife because of other drivers like competition with livestock, predation, and human activities like agriculture and settlements that block migration or dispersal of wildlife from the high temperature areas to cool and wet areas. The restricted access to key resources during these harsh conditions may lead to high mortalities of the affected species. Dispersal is a vital biological process that displays strong difference among species 
and regions [41]. At regional and local level, warming can hasten species' physiological and biological rates with rising impacts on population dynamics and species interactions [42].

In our study the species that will be affected most by the increasing temperature are; the buffalo, Thomson's gazelle, warthog, waterbuck, and wildebeest. If temperatures continue rising unabated in Kajiado, these species are anticipated to lose more than $50 \%$ of their range by 2070 . Most of these animals have a small range especially the big body size, and are water dependent animals. Body size of mammals have been positively correlated with extermination risk [32] [34]. Energetic constraints are deemed to limit maximum body size of larger mammals which require more energy, and therefore more land area than smaller mammals [43]. Large mammals also have less body surface area for a unit of body mass, and therefore have slower heat loss per kilogram of body mass, in cool environments, than do smaller mammals [44].

Our study has shown that increasing temperatures are affecting wildlife particularly in the Kenyan Savanna. This is the fact that cannot be ignored by conservation managers. We have established that increasing temperatures are leading to range loss among the large herbivores. In their study Ojwang et al., (2006) documented range contraction based on analyses of the DRSRS data for several individual rangeland counties, including Kajiado. Several other studies in the savannas have reported devastating declines in wildlife numbers in Kajiado county [23] [24] [35] [45]. Therefore immediate intervention strategies are needed if wildlife is to be conserved for the future generations. The following suggestions can be explored: 1) The government should focus conservation resources in the maintenance and continued survival on species that are highly threatened (buffalo, Thomson's gazelle, warthog, waterbuck, and wildebeest) that might become extinct as a result of global climate change. 2) The species at risk of extinction can be moved from sites that are becoming unsuitable due to global climate change to other sites that are deemed more favorable for their continued existence. 3) Reduce pressure on species from non-climate stressors to give the animals maximum flexibility to evolve responses to climate change. 4) Incorporate predicted climate change impacts into wildlife and conservation managements plans since studies have shown that climate change is not addressed in many existing natural resource plans [46]. In addition the Kenya Wildlife Conservation and Management Act 2013 should be reviewed to ensure that their provisions are consistent with the needs of managers dealing with the effects of climate change. New legislative tools or regulations may be necessary to address specific climate-change impacts, [47] and [48] indicate that impacts of climate change on biodiversity at all levels implies that ecologists must swiftly rise to the challenge of offering scientific guidance for the improvement of conservation strategies.

\section{Conclusion}

The present study only examined the impact of increasing temperatures on the 
range of about 15 large herbivore species based on future climate scenarios. More localized studies should explore both rainfall and temperature impacts on other species in the study area using high resolution data and other environmental variables. The findings of this study highlight the potential for climate change to significantly add more burdens to large herbivores in Kenyan savanna as they struggle with other stressors to survive. From this study the following conclusions can be made: 1) in a world of limited dispersal opportunities, the range size occupied by species is crucial to their survival and determines their extinction risk more than any other factor; 2) species threat assessment will benefit strongly from extending and including knowledge of species percentage range loss over the years; 3 ) conservation efforts will benefit from the placement of alternative corridors in strategic locations and along key migratory corridors to promote connectivity especially in areas with intensive human land use. It is widely accepted that landscape connectivity is an important strategy that enables species to move through a matrix of interconnected habitats in order to escape from unsuitable climatic conditions [46].

\section{Acknowledgements}

The authors gratefully acknowledge funding support provided through the $\mathrm{Na}$ tional Commission for Science, Technology and Innovation (NACOSTI) under the Research Endowment Fund $6^{\text {th }}$ call postgraduate 2014/2015 grantss. We thank the Directorate of Resource Surveys and Remote Sensing of Kenya (DRSRS) for permission to use the aerial survey data. We are grateful to Hussen Seid and Herbert Misiani of ICPAC for providing the projected temperature data. MYS was supported by the Pathways to Resilience in Semi-Arid Economies (PRISE) Project 5-Property regimes, investments and economic development in the context of climate change in semi-arid lands of East Africa. The authors also wish to thank reviewers for their suggestions, which resulted in the improvement of the manuscript.

\section{References}

[1] Parry, M.L., Canziani, O.F., Palutikof, J.P., van der Linden, P.J. and Hanson, C.E. (2007) Climate Change 2007-Impacts, Adaptation and Vulnerability: Contribution of Working Group II to the Fourth Assessment Report of the Intergovernmental Panel on Climate Change. Cambridge University Press, Cambridge, 976 p.

[2] Hartmann, D.L., Klein Tank, A.M.G., Rusticucci, M., Alexander, L.V., Brönnimann, S., Charabi, Y.A.R., Dentener, F.J., Dlugokencky, E.J., Easterling, D.R., Kaplan, A., Soden, B.J., Thorne, P.W., Wild, M. and Zhai, P. (2013) Observations: Atmosphere and Surface. In: Stocker, T.F., Qin, D., Plattner, G.-K., Tignor, M., Allen, S.K., Boschung, J., Nauels, A., Xia, Y., Bex, V. and Midgley, P.M., Eds., Climate Change 2013-The Physical Science Basis. Working Group I Contribution to the Fifth Assessment Report of the Intergovernmental Panel on Climate Change, Cambridge University Press, Cambridge, 159-254.

https://doi.org/10.1017/CBO9781107415324.008

[3] Collins, M., Knutti, R., Arblaster, J., Dufresne, J.-L., Fichefet, T., Friedlingstein, P., 
Gao, X., Gutowski, W.J., Johns, T., Krinner, G., Shongwe, M., Tebaldi, C., Weaver, A.J. and Wehner, M. (2013) Long-Term Climate Change: Projections, Commitments and Irreversibility. In: Stocker, T.F., Qin, D., Plattner, G.-K., Tignor, M., Allen, S.K., Boschung, J., Nauels, A., Xia, Y., Bex, V. and Midgley, P.M., Eds., Climate Change 2013-The Physical Science Basis. Working Group I Contribution to the Fifth Assessment Report of the Intergovernmental Panel on Climate Change, Cambridge University Press, Cambridge, 1029-1136.

https://doi.org/10.1017/CBO9781107415324.024

[4] Piniewski, M., Mezghani, A., Szcześniak, M. and Kundzewicz, Z. (2017) Regional Projections of Temperature and Precipitation Changes: Robustness and Uncertainty Aspects. Meteorologische Zeitschrift, 26, 223-234.

[5] Stocker, T.F., Qin, D., Plattner, G.-K., Tignor, M., Allen, S.K., Boschung, J., Nauels, A., Xia, Y., Bex, V. and Midgley, P.M. (2013) Climate Change 2013-The Physical Science Basis: Working Group I Contribution to the Fifth Assessment Report of the Intergovernmental Panel on Climate Change. Cambridge University Press, Cambridge, $1535 \mathrm{p}$.

[6] Bellard, C., Bertelsmeier, C., Leadley, P., Thuiller, W. and Courchamp, F. (2012) Impacts of Climate Change on the Future of Biodiversity. Ecology Letters, 15, 365-377. https://doi.org/10.1111/j.1461-0248.2011.01736.x

[7] Msoffe, F.U., Ogutu, J.O., Kaaya, J., Bedelian, C., Said, M.Y., Kifugo, S.C. and Thirgood, S. (2009) Participatory Wildlife Surveys in Communal Lands: A Case Study from Simanjiro, Tanzania. African Journal of Ecology, 48, 727-735.

https://doi.org/10.1111/j.1365-2028.2009.01170.x

[8] Staudinger, M.D, Carter, S.L., Cross, M.S., Dubois, N.S., Duffy, J.E., Enquist, C., Griffis, R., Hellmann, J., Lawler, J., O’Leary, J., Morrison, S.A., Sneddon, L., Stein, B.A., Thompson, L. and Turner, W. (2013) Biodiversity in a Changing Climate: A Synthesis of Current and Projected Trends in the US. Frontiers in Ecology and the Environment, 11, 465-464. https://doi.org/10.1890/120272

[9] Niang, I., Ruppel, O.C., Abdrabo, M.A., Essel, A., Lennard, C., Padgham, J. and Urquhart, P. (2014) Africa. In: Barros, V.R., Field, C.B., Dokken, D.J., Mastrandrea, M.D., Mach, K.J., Bilir, T.E., Chatterjee, M., Ebi, K.L., Estrada, Y.O., Genova, R.C., Girma, B., Kissel, E.S., Levy, A.N., MacCracken, S., Mastrandrea, P.R. and White, L.L., Eds., Climate Change 2014-Impacts, Adaptation and Vulnerability. Part B: Global and Sectoral Aspects. Working Group II Contribution to the IPCC Fifth Assessment Report, Cambridge University Press, Cambridge, 1199-1265.

[10] Res, C., Hulme, M., Doherty, R., Ngara, T., New, M. and Lister, D. (2001) African Climate Change : 1900-2100. Climate Research, 17, 145-168.

https://doi.org/10.3354/cr017145

[11] Coe, R. and Stern, R.D. (2011) Assessing and Addressing Climate-Induced Risk in Sub-Saharan Rainfed Agriculture: Lessons Learned. Experimental Agriculture, 47, 395-410. https://doi.org/10.1017/S001447971100010X

[12] Thomas, C.D., Cameron, A., Green, R.E., Bakkenes, M., Beaumont, L.J., Collingham, Y.C., Erasmus, B.F.N., de Siqueira, M.F., Grainger, A., Hannah, L., Hughes, L., Huntley, B., van Jaarsveld, A.S., Midgley, G.F., Miles, L., Ortega-Huerta, M.A., Peterson, A.T., Phillips, O.L. and Williams, S.E. (2004) Extinction Risk From Climate Change. Nature, 427, 145-148. https://doi.org/10.1038/nature02121

[13] Ceballos, G., Ehrlich, P.R. and Dirzo, R. (2017) Biological Annihilation via the Ongoing Sixth Mass Extinction Signaled by Vertebrate Population Losses and Declines. Proceedings of the National Academy of Sciences, 114, E6089-E6096. https://doi.org/10.1073/pnas.1704949114 
[14] Parmesan, C., Burrows, M.T., Duarte, C.M., Poloczanska, E.S., Richardson, A.J., Schoeman, D.S. and Singer, M.C. (2013) Beyond Climate Change Attribution in Conservation and Ecological Research. Ecology Letters, 16, 58-71. https://doi.org/10.1111/ele.12098

[15] Monzón, J., Moyer-Horner, L. and Palamar, M.B. (2011) Climate Change and Species Range Dynamics in Protected Areas. BioScience, 61, 752-761. https://doi.org/10.1525/bio.2011.61.10.5

[16] Wiens, J.J. (2016) Climate-Related Local Extinctions Are Already Widespread among Plant and Animal Species. PLoS Biology, 14, e2001104. https://doi.org/10.1371/journal.pbio.2001104

[17] Jetz, W., Wilcove, D.S. and Dobson, A.P. (2007) Projected Impacts of Climate and Land-Use Change on the Global Diversity of Birds. PLoS Biology, 5, 1211-1219. https://doi.org/10.1371/journal.pbio.0050157

[18] Sekercioglu, C.H., Schneider, S.H., Fay, J.P. and Loarie, S.R. (2008) Climate Change, Elevational Range Shifts, and Bird Extinctions. Conservation Biology, 22, 140-150. https://doi.org/10.1111/j.1523-1739.2007.00852.x

[19] Said, M.Y., Ogutu, J.O., Kifugo, S.C., Makui, O., Reid, R.S. and de Leeuw, J. (2016) Effects of Extreme Land Fragmentation on Wildlife and Livestock Population Abundance and Distribution. Journal for Nature Conservation, 34, 151-164. https://doi.org/10.1016/j.jnc.2016.10.005

[20] Ogutu, J.O., Piepho, H., Said, M.Y., Ojwang, G.O., Njino, L.W., Kifugo, S.C. and Wargute, P.W. (2016) Extreme Wildlife Declines and Concurrent Increase in Livestock Numbers in Kenya : What Are the Causes? PLoS ONE, 11, e0163249. https://doi.org/10.1371/journal.pone.0163249

[21] Moss, R.H., Edmonds, J.A., Hibbard, K.A., Manning, M.R., Rose, S.K., van Vuuren, D.P., Carter, T.R., Emori, S., Kainuma, M., Kram, T., et al. (2010) The Next Generation of Scenarios for Climate Change Research and Assessment. Nature, 463, 747-756. https://doi.org/10.1038/nature08823

[22] Norton-Griffiths, M. (1978) Counting Animals. Handbook 1. 2nd Edition, African Wildlife Foundation, Nairobi.

[23] Ogutu, J.O., Piepho, H.-P., Said, M.Y. and Kifugo, S.C. (2014) Herbivore Dynamics and Range Contraction in Kajiado County Kenya: Climate and Land Use Changes, Population Pressures, Governance, Policy and Human-Wildlife Conflicts. The Open Ecology Journal, 7, 9-31. https://doi.org/10.2174/1874213001407010009

[24] Western, D., Groom, R. and Worden, J. (2009) The Impact of Subdivision and Sedentarization of Pastoral Lands on Wildlife in an African Savanna Ecosystem. Biological Conservation, 142, 2538-2546. https://doi.org/10.1016/j.biocon.2009.05.025

[25] Bhola, N., Ogutu, J.O., Said, M.Y., Piepho, H.-P. and Olff, H. (2012) The Distribution of Large Herbivore Hotspots in Relation to Environmental and Anthropogenic Correlates in the Mara region of Kenya. Journal of Animal Ecology, 81, 1268-1287. https://doi.org/10.1111/j.1365-2656.2012.02000.x

[26] Coe, M.D., Cummings, D.H. and Phillipson, J. (1976) Biomass and Production of Large Herbivores in Relation to Rainfall and Primary Production. Oecologia, 22, 341-354. https://doi.org/10.1007/BF00345312

[27] IPCC (2013) Summary for Policymakers. In: Stocker, T.F., Qin, D., Plattner, G.-K., Tignor, M., Allen, S.K., Boschung, J., Nauels, A., Xia, Y., Bex, V. and Midgley, P.M., Eds., Climate Change 2013- The Physical Science Basis. Working Group I Contribution to the Fifth Assessment Report of the Intergovernmental Panel on Climate Change, Cambridge University Press, Cambridge. 
[28] Riahi, K., Rao, S., Krey, V., Cho, C., Chirkov, V., Fischer, G. and Rafaj, P. (2011) RCP 8.5-A Scenario of Comparatively High Greenhouse Gas Emissions. Climatic Change, 109, 33-57. https://doi.org/10.1007/s10584-011-0149-y

[29] van Vuuren, D.P., Edmonds, J., Kainuma, M., Riahi, K., Thomson, A., Hibbard, K. and Rose, S.K. (2011) The Representative Concentration Pathways: An Overview. Climatic Change, 109, 5-31. https://doi.org/10.1007/s10584-011-0148-z

[30] Giorgi, F. (2006) Climate Change Hot-Spots. Geophysical Research Letters, 33, 1-4. https://doi.org/10.1029/2006GL025734

[31] Burnham, K.P. and Anderson, D.R. (2002) Model Selection and Multimodel Inference: A Practical Information-Theoretic Approach. 2nd Edition, Springer, Berlin.

[32] Davidson, A.D., Hamilton, M.J., Boyer, A.G., Brown, J.H. and Ceballos, G. (2009) Multiple Ecological Pathways to Extinction in Mammals. Proceedings of the National Academy of Sciences, 106, 10702-10705. https://doi.org/10.1073/pnas.0901956106

[33] Hilbers, J.P., Schipper, A.M., Hendriks, A.J., Verones, F. and Pereira, H.M. (2016) An Allometric Approach to Quantify the Extinction Vulnerability of Birds and Mammals. Ecology, 97, 615-626. https://doi.org/10.1890/14-2019.1

[34] Cardillo, M., Mace, G.M., Jones, K.E., Bielby, J., Bininda-emonds, O.R.P., Sechrest, W. and Purvis, A. (2005) Multiple Causes of High Extinction Risk in Large Mammal Species. Science, 1067, 1239-1241. https://doi.org/10.1126/science.1116030

[35] Ogutu, J.O., Owen-Smith, N., Piepho, H.-P., Said, M.Y., Kifugo, S.C., Reid, R.S., Gichohi, H., Kahumbu, P. and Andanje, S (2013) Changing Wildlife Populations in Nairobi National Park and Adjoining Athi-Kaputiei Plains: Collapse of the Migratory Wildebeest. Open Conservation Biology Journal, 7, 11-26. https://doi.org/10.2174/1874839201307010011

[36] Field, C.B., Barros, V.R., Mach, K.J., Mastrandrea, M.D., van Aalst, M., Adger, W.N., Arent, D.J., Barnett, J., Betts, R., Bilir, T.E., Birkmann, J., Carmin, J., Chadee, D.D., Challinor, A.J., Chatterjee, M., Cramer, W., Davidson, D.J., Estrada, Y.O., Gattuso, J.-P., Hijoka, Y., Hoegh-Guldberg, O., Huang, H.-Q., Insarov, G.E., Jones, R.N., Kovats, R.S., et al. (2014) Technical Summary. Climate Change 2014-Impacts, Adaptation and Vulnerability: Part A: Global and Sectoral Aspects. Working Group II Contribution to the IPCC Fifth Assessment Report, Cambridge University Press, Cambridge, 35-94. https://doi.org/10.1017/CBO9781107415379.004

[37] Moss, C.J., Croze, H. and Lee, P.C. (2011) The Amboseli Elephants: A Long-Term Perspective on a Long-Lived Mammal. University of Chicago Press, Chicago, IL, 383 p. https://doi.org/10.7208/chicago/9780226542263.001.0001

[38] Ishida, Y., Van Coeverden de Groot, P.J., Leggett, K.E.A., Putnam, A.S., Fox, V.E., Lai, J., Boag, P.T., Georgiadis, N.J. and Roca, A.L. (2016) Genetic Connectivity across Marginal Habitats: The Elephants of the Namib Desert. Ecology and Evolution, 6, 6189-6201. https://doi.org/10.1002/ece3.2352

[39] Junker, J., van Aarde, R.J. and Ferreira, S.M. (2008) Temporal Trends in Elephant Loxodonta africana Numbers and Densities in Northern Botswana: Is the Population Really Increasing? Oryx, 42, 58-65. https://doi.org/10.1017/S0030605308000756

[40] Ojwang', G.O., Wargute, P.W., Said, M.Y., Worden, J.S., Davidson, Z., Muruthi, P. and Okita-Ouma, B. (2017) Wildlife Migratory Corridors and Dispersal Areas: Kenya Rangelands and Coastal Terrestrial Ecosystems. Tourist Management Perspectives. http://www.kws.go.ke/content/launch-report-wildlife-corridors-and-dispersal-areas

[41] Clobert, J., Danchin, É., Dhondt, A.A. and Nichols, J.D. (2001) Dispersal. Oxford University Press, New York. 
[42] Grainger, T.N., Germain, R.M., Jones, N.T. and Gilbert, B. (2017) Predators Modify Biogeographic Constraints on Species Distributions in an Insect Metacommunity. Ecology, 98, 851-860. https://doi.org/10.1002/ecy.1712

[43] Smith, F.A. and Lyons, S.K. (2011) How Big Should a Mammal Be? A Macroecological Look at Mammalian Body Size over Space and Time. Philosophical Transactions of the Royal Society B, 366, 2364-2378. https://doi.org/10.1098/rstb.2011.0067

[44] Jessen, C. (2001) Temperature Regulation in Humans and Other Mammals. Springer-Verlag, Berlin. https://doi.org/10.1007/978-3-642-59461-8

[45] Western, D. and Nightingale, D. (2004) Environmental Change and the Vulnerability of Pastoralists to Drought: A Case Study of the Maasai in Amboseli, Kenya. Africa Environment Outlook Case Studies: Human Vulnerability to Environmental Change, 31-50.

[46] Hannah, L., Midgley, G., Andelman, S., Araújo, M., Hughes, G., Martinez-Meyer, E., Pearson, R. and Williams, P. (2007) Protected Area Needs in a Changing Climate. Frontiers in Ecology and the Environment, 5, 131-138.

[47] Araújo, M.B., Alagador, D., Cabeza, M., Nogués-Bravo, D. and Thuiller, W. (2011) Climate Change Threatens European Conservation Areas. Ecology Letters, 14, 484492. https://doi.org/10.1111/j.1461-0248.2011.01610.x

[48] Dawson, T.P., Jackson, S.T., House, J.I., Prentice, I.C. and Mace, G.M. (2011) Beyond Predictions: Biodiversity Conservation in a Changing Climate. Science, 332, 53-58. https://doi.org/10.1126/science.1200303

\section{Appendix}



Photo source: Ron beaton.

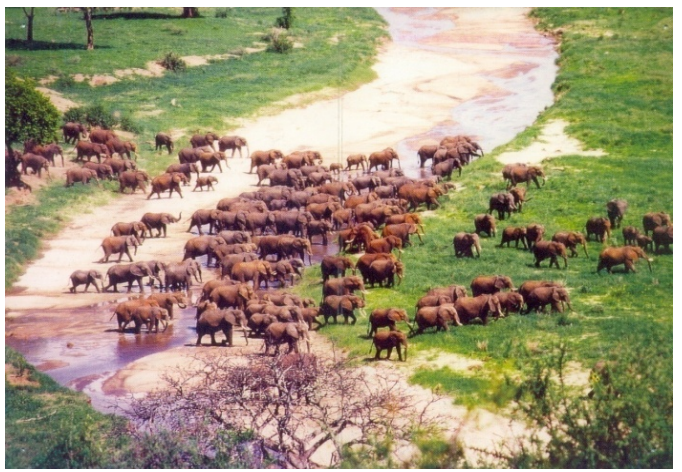

Photo source: Fortunata msoffe. 